Article

\title{
Youth and the Future of Community Forestry
}

\author{
James P. Robson ${ }^{1, *}$, Sarah J. Wilson ${ }^{2}$, Constanza Mora Sanchez ${ }^{1}$ and Anita Bhatt ${ }^{1}$ \\ 1 School of Environment and Sustainability (SENS), University of Saskatchewan, \\ Saskatoon, SK S7N 5B5, Canada; constanza.mora@usask.ca (C.M.S.); anita.bhatt@usask.ca (A.B.) \\ 2 School of Environmental Studies, University of Victoria, Victoria, BC V8W 2Y2, Canada; sjwil@umich.edu \\ * Correspondence: james.robson@usask.ca
}

Received: 18 September 2020; Accepted: 22 October 2020; Published: 24 October 2020

check for updates

\begin{abstract}
Forests managed by Indigenous and other local communities generate important benefits for livelihood, and contribute to regional and global biodiversity and carbon sequestration goals. Yet, challenges to community forestry remain. Rural out-migration, for one, can make it hard for communities to maintain broad and diverse memberships invested in local forest commons. This includes young people, who can contribute critical energy, ideas, and skills and are well positioned to take up community forest governance and work, but often aspire to alternative livelihoods and lifestyles. Through an initiative called the Future of Forest Work and Communities, we sought to connect researchers and practitioners with young people living in forest regions, and explore whether community forestry is, or could be, a viable option for them in a globalising world. We achieved this through two phases of qualitative research: youth visioning workshops and questionnaires conducted in 14 forest communities and regions across 9 countries, and a more in-depth case study of two forest communities in Oaxaca, Mexico, using participant observation and semi-structured interviews. We found important synergies across sites. Youth held strong connections with their communities and local forests, but work and/or study aspirations meant many would likely leave their home communities (at least for a time). Community forestry was not seen as an obvious livelihood pathway by a majority of youth, although interest in forest work was evident through participation in several workshop activities. As community leadership and support organisations consider community forestry as an engine of local development, the research highlights the importance of engaging local youth to understand their interests and ideas, and thus identify practical and meaningful ways to empower them as community and territorial actors.
\end{abstract}

Keywords: forests; youth; youth aspirations; community forestry; migration; mobility; rural-urban linkages; cultural norms; livelihoods

\section{Introduction}

Local and Indigenous communities are important actors in forest governance and conservation [1,2]. In Latin America, for example, Indigenous and other local communities either own or have use and management rights to over 200 million square kilometres of forests [3]. Globally, community forestry $(\mathrm{CF})^{1}$ has become an important contributor to climate mitigation and biodiversity conservation goals [2-5] as well as to rural economies [6-8].

Support for CF has often focused on securing land and resource rights and increasing the economic opportunities that can accrue from forests [5]. The embedded assumption is that, given secure rights

1 Community forestry, as used here, refers to a diversity of arrangements under which Indigenous and other local communities with access to forest resources, participate in forest use and management practices under some degree of autonomy from or in collaboration with the; state. 
and benefit flows, forest communities will manage forests better, see incomes, livelihoods and subjective wellbeing improve, and protect forests to ensure their future integrity $[5,9,10]$. Yet, the idea that people will remain in and manage the forests they control is tempered by the numbers leaving well-supported communities with established forest tenure [11,12].

Over recent years, rural resource-dependent communities have experienced three interlocking social transformations. First, traditional forms of land use have declined and rural livelihoods have become less territorially based as rural-urban linkages have strengthened [13-17]. Second, driven by falls in fertility levels and rises in life expectancies, families have become smaller and rural populations have both contracted and aged $[18,19]$. Third, mobility and migration have exacerbated these trends, bringing in remittances to supplement and sometimes replace land-based income, and provide new opportunities for work and education that take youth and working-aged people away from their communities [12]. Transformations of this kind pose challenges to CF: communities may experience labour shortages, and underused and under-managed forest commons can become prone to illegal harvesting and deforestation $[19,20]$.

The reality of smaller and aging rural populations has generated calls for more meaningful livelihood opportunities in rural settings, which could include forest-related work [21,22]. Yet, in a CF context, communities can often suffer from a "liability of smallness" when competing in domestic and global markets [23], a lack of business skills and access to financial services or niche markets [24], and operate within sometimes adverse policy and regulatory environments [24]. Then there are the less studied "internal" challenges affecting how communities govern their forests and organise forest work [25]. Across global regions, CF arrangements are often dominated by men, with women and youth underrepresented [26-28]. While the role of women in forest use and management has attracted research attention [29-32], knowledge of youth, their perspectives, and their participation in environmental practice and stewardship is more limited (see [33]), although these topics are gaining traction in rural resource management such as small-scale agriculture [34,35]. Similarly, while researchers have solicited youth perceptions of environmental change [36,37], the implications for youth in resource management and decision-making remain unclear [38,39] and few have focused on building youth capacity as environmental actors (e.g., [40,41]), including in forestry [21,40].

These are knowledge gaps that need to be addressed. For communities, and the practitioners and academics that support and study them, the realisation that youth—through their choices and actions - can (and arguably need) to play a leading role in shaping community and forest futures has increased [38]. In communities with too few young people, or where too many opt for off-land livelihoods, the social organisation, collective labour, ways of knowing, and local institutions that underpin shared land use and management can weaken [12]. At the same time, youth may be open to forest work opportunities, which may become more numerous as communities improve applications of REDD+ and other PES projects as part of their CF strategies [42-44], and a new landscape of forest use and conservation emerges [45].

Better understanding of youth aspirations and youth-community-forest linkages can help in developing appropriate and forward-thinking CF strategies, policies and practices [46-48]. It is here that the current paper makes an important contribution-presenting findings from youth-focused empirical research conducted in several global regions: a series of visioning workshops with youth living in forest regions in Asia, Africa and the Americas; and, a more in-depth case study from Oaxaca, Mexico, a global leader in community forestry [49]. Working in places where collective governance dictates how forests are accessed and used, and benefits distributed, we learnt from local youth about their work and life plans, their connections to local forests (and territory more generally), and their views on community decision-making processes and structures-all areas with the potential to influence youth mobility [48,50-52] and their potential as community actors.

Migration can distance community members, including youth, from customary lands and territories, complicating the interactions that reaffirm shared norms of trust and reciprocity [53-55]. For youth, migration and associated cultural change can separate them both physically and emotionally 
from home and decrease their reliance on territorial resources for livelihood-making it more difficult for their communities of origin to maintain the place-based social relationships that embed local commons [12,56,57]. We wanted to find out if this was taking place or likely to happen in the future, by engaging youth and inviting them to share their perspectives, intentions and ideas. It meant asking youth whether forest-related work is something that interests them. It meant asking youth and community leaders about current youth-community integration and relations, and what might be needed so that youth could contribute to securing a sustainable future for their communities and territories. Our findings would also allow us to consider whether efforts to engage youth might influence institutional choice [58,59], whereby community norms, institutions and organisational structures adapt to reflect and encompass emergent or changing member profiles, identities, ideas, and voice [60-62]. In other words, might youth become the catalyst for new community configurations (after $[30,62,63])$ to unfold?

The paper consists of five main sections. Following this Introduction, we describe and explain our study sites and methods. We then present our main study results, organised into the following thematic categories: youth livelihood and study aspirations; youth mobility; what influences mobility choices; changes youth want to see in their communities; youth-territory-forest connections and values; and youth interest in forestry and forest-related work. We then discuss these results in the broader context of community and forest futures, and end with a brief conclusion.

\section{Methods}

Data collection took place from 2017 to 2019, split into two phases: (I) youth visioning workshops (2017-2018); and, (II) ethnographic fieldwork in two forest communities in Oaxaca, Mexico (2019). Both phases of research, described in detail below, were approved by the University of Saskatchewan's Research Ethics Board.

\subsection{Phase One}

Youth visioning workshops were organised in 14 locations in forest regions in Africa, Asia, and the Americas (Table 1).

Table 1. Workshop locations and participant profiles.

\begin{tabular}{|c|c|c|c|c|c|c|}
\hline Country & Community & $\begin{array}{c}\text { No. of } \\
\text { Participants }\end{array}$ & $\begin{array}{c}\text { Female } \\
\text { Participation }\end{array}$ & $\begin{array}{c}\text { Age Range } \\
\text { of Participants }\end{array}$ & $\begin{array}{l}\text { Average Age } \\
\text { of Participants }\end{array}$ & $\begin{array}{c}\text { No. of } \\
\text { Participants } \\
\text { Born in } \\
\text { Community }\end{array}$ \\
\hline 9 countries & 14 workshops ${ }^{2}$ & 198 & $46 \%$ & $11-37$ & 20 & 126 \\
\hline Canada & Poplar River FN & 10 & $20 \%$ & $16-26$ & 19 & 6 \\
\hline Canada & $\begin{array}{l}\text { Lac Simon } \\
\text { San Juan }\end{array}$ & 6 & $80 \%$ & $26-37$ & 30 & tbc \\
\hline Mexico & $\begin{array}{c}\text { Evangelista } \\
\text { Analco }\end{array}$ & 16 & $56 \%$ & $11-27$ & 17 & 7 \\
\hline Mexico & Jalapa del Valle & 16 & $44 \%$ & $13-22$ & 16 & 10 \\
\hline Bolivia & Primero de Mayo & 13 & $69 \%$ & $13-19$ & 16 & 0 \\
\hline Bolivia & $\begin{array}{l}\text { San Antonio de } \\
\text { Lomerio }\end{array}$ & 13 & $38 \%$ & $15-26$ & 18 & 8 \\
\hline Bolivia & El Puquio & 15 & $53 \%$ & $16-19$ & 17 & 8 \\
\hline Nepal & $\begin{array}{c}\text { Jyalachiti CF, } \\
\text { Panauti }\end{array}$ & 18 & $44 \%$ & $19-29$ & 25 & 15 \\
\hline Peru & $\begin{array}{l}\text { Madre de Dios } \\
\text { (multiple } \\
\text { communities) }\end{array}$ & 14 & $43 \%$ & $15-34$ & 21 & 12 \\
\hline Guatemala & Uaxactún & 15 & $33 \%$ & $15-29$ & 19 & 12 \\
\hline Uganda & Lwanunda & 19 & $47 \%$ & $13-25$ & 19 & 19 \\
\hline Uganda & Buyege & 16 & $56 \%$ & $16-29$ & 21 & 7 \\
\hline Tanzania & Geita & 15 & $47 \%$ & $19-32$ & 25 & 10 \\
\hline Philippines & General Nakar & 12 & $42 \%$ & $15-18$ & 17 & 12 \\
\hline
\end{tabular}


These workshops engaged youth participants in conversations about their lives, their ideas, and their visions for the future. Each workshop followed a standardised format and set of activities (Supplementary Materials, Table S1), which allowed common themes to be identified across locations, while enabling insights and ideas specific to place to be captured. Youth participants also completed a questionnaire (Supplementary Materials, Table S2) where they provided information about their educational and work aspirations, their migration experiences and plans, and level of forest use, knowledge, and dependence.

We selected communities ${ }^{3}$ based on several criteria: people-forest interactions, level of forest dependence ${ }^{4}$, youth migration issues (or alternatively, a strong and vibrant youth presence), employment and education challenges, and expressed interest in hosting a workshop. Supplementary Material (Table S3) provides further background on the communities and locales where the 14 workshops took place. In addition to the above criteria, we prioritised communities where the lead authors and their collaborators had strong working relationships, which were essential in getting community leadership on board and identifying local people who could become part of workshop facilitation teams.

For each workshop, youth participants were identified and invited in accordance with local custom. Participation was voluntary. Specific age ranges were not set, given that definition of what constitutes "youth" varies across countries and cultures, but ages 15 to 30 were given as general guidance. Neither did we specify a set number of participants but considered 10 to 15 as ideal given planned activities. Beyond questions of age and number of participants, we were keen that invited/selected youth incorporated differences in age, gender, educational attainment, and employment status.

In most workshops, there was an even split between male and female participants. The exceptions were Primero de Mayo (Bolivia) and Lac Simon (Quebec, Canada), where participants were mainly female, and Poplar River First Nation (Manitoba, Canada) where participants were overwhelmingly male. Age ranges varied across workshops, but most were in their mid/late-teens to early/mid-twenties. The pre-workshop questionnaire gathered information about participants' birthplace and time spent living in the home community (for those born elsewhere). Over a third of participants (72, or 36\%) were born outside of the community. A minority of workshops-Analco (Mexico); Primero de Mayo, San Antonio de Lomerio, El Puquio (Bolivia), Buyege (Uganda), and Geita (Tanzania)—accounted for most of these. These include populations that have grown through immigration from other regions (Bolivian cases) or have decades-long histories of out-migration with patterns of return (Analco, Mexico). Of the 72 participants who were not born in their current home community, only 12 had arrived in the previous 5 years-nearly all accounted for by the Buyege (Uganda) and Geita (Tanzania) workshops. Most participants across locations were single and without children. Three workshops stood out for a relatively high number of married participants and/or those with children-Panauti (Nepal), Buyege (Uganda), and Geita (Tanzania).

\subsection{Phase Two}

Case studies of two communities (Figure 1)—San Juan Evangelista Analco (Analco) and Jalapa del Valle (Jalapa), Oaxaca, Mexico-were conducted over a four-month period between May and September 2019. This work enabled more in-depth analysis of youth perspectives.

2 While 14 workshops took place, much of the data presented in the Results are based on just 13 of these, because analysis for Lac Simon (Canada) was incomplete.

3 Community, as used here, refers to a group of people who self-identify as members of a particular community, which in turn has a home locality (or localities) and customary lands that include forest. However, community membership does not necessarily depend upon maintaining residence in the home locality or localities.

4 Level of forest-dependence, as used here, was gauged by workshop facilitators in conjunction with community leaderships and determined by looking at forest dependence generally in the region where the workshop took place (and not in relation to other workshop locations). 


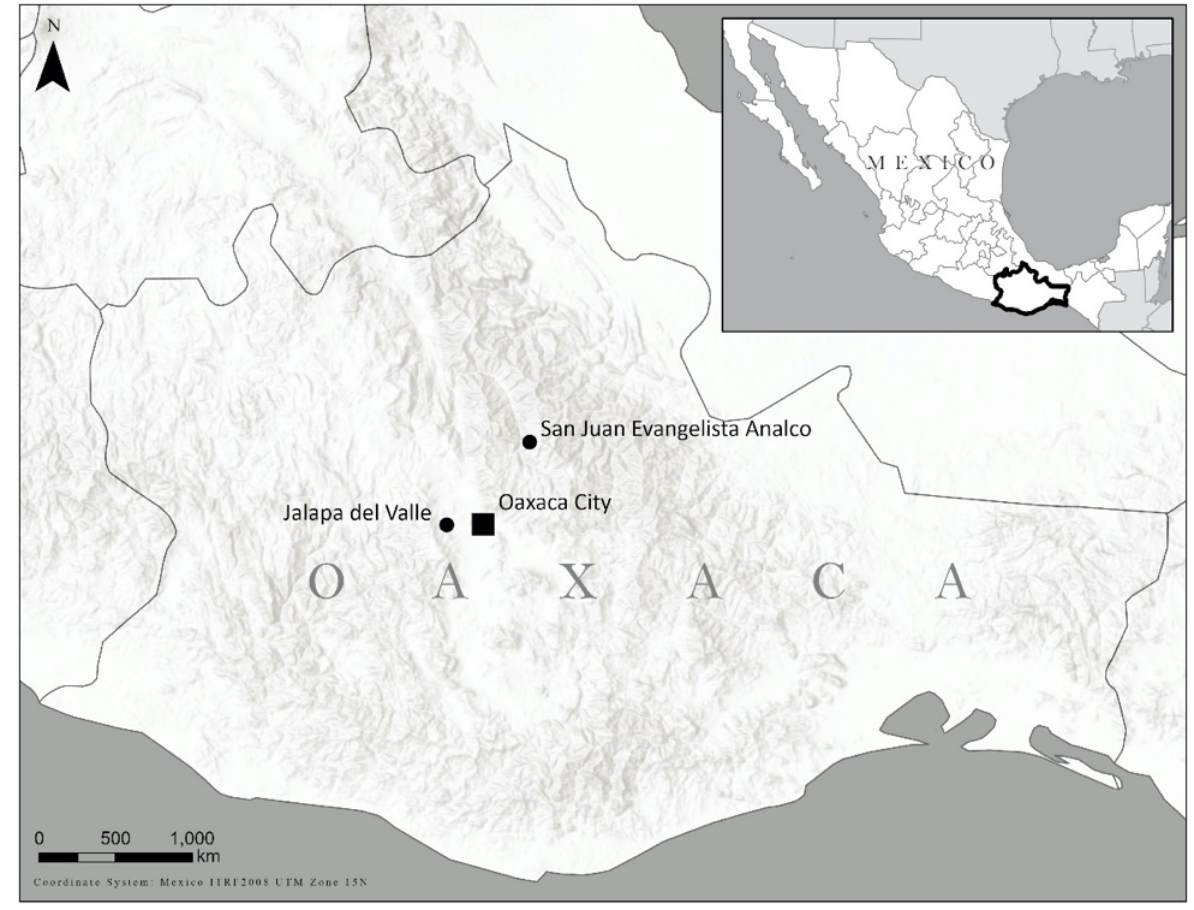

Figure 1. Location of study communities in Oaxaca, Mexico.

Analco is located in Oaxaca's northern highlands (Sierra Norte), $60 \mathrm{~km}$ or a 2-h drive north of Oaxaca City (state capital). It had a population of 460 inhabitants in 2018, from a peak of 986 in $1970^{5}$. Over the past decade and a half, the community has focused attention on territorial resource use and planning. It began formal forest management in 2013, won a national award for community forestry in 2016, and has held Sustainable Forest Management (SFM) certification since 2017. Jalapa is located in Oaxaca's central valleys (Valles Centrales) region, $20 \mathrm{~km}$ or a 45-minute drive from Oaxaca City. The community had a resident population of 1543 in 2018. In the mid-1970s, Jalapa banned logging in its (degraded) forests, designating them as conservation areas. The community won a national prize for nature conservation in 2013. In 2017, following problems (mountain pine beetle, forest fires) associated with its "no-touch" forest policy, formal forest management was proposed. In 2019, Jalapa began logging under a ten-year, community forest management plan. Leadership in both communities have said they are keen to engage youth in order to keep community forestry viable.

Primary data were collected via 64 semi-structured interviews; 34 with youth, and 30 with community leaders, older adult community members, and experts from academia, NGOs, and government studying or supporting the community forest sector in Oaxaca. Interviews covered several themes: youth-held aspirations (work, study, family, future plans, the meaning of success), community life (duties/responsibilities as community members, the assembly and community decision-making), forests (collective forest management, attachment to local forests and the land, interest in forest work), and community futures.

Before presenting our study results, it is important to acknowledge the limitations of the research. Youth who participated in Phase 1 and Phase 2 were not randomly selected and do not constitute a representative sample of youth in their communities. While we invited youth participants of differing age groups, genders, and educational and work backgrounds, their involvement was voluntary. Consequently, the data presented here provide no more than a snapshot of youth-held aspirations, opinions, perspectives, and ideas in the places where we worked. Findings from these workshops and

5 Sistema Nacional de Información Estadística y Geográfica (INEGI). “Archivo histórico de localidades”. Accessed July, 2020. https://www.inegi.org.mx/app/archivohistorico/ 
communities are not generalisable to the broader rural population of the regions and countries where study sites were located.

\section{Results}

\subsection{Youth Livelihood and Study Aspirations}

We asked youth participants about their work and study aspirations. Figure 2 shows the frequency of occurrence of career choices across workshop locations. Certain careers held appeal at most if not all locations where workshops took place; with engineering, teaching, and medicine leading the way. Of the jobs mentioned in more than five workshop locations, only two were natural resources-focused (forestry and farming). Overall, plans centred around a desire for steady, year-round, and reasonably well-paid work. Most required post-secondary education and few occupations were widely available in their home communities. The number of youth who aspired to be self-employed (farmer, mechanic, hairdresser, business owner) was also notable.

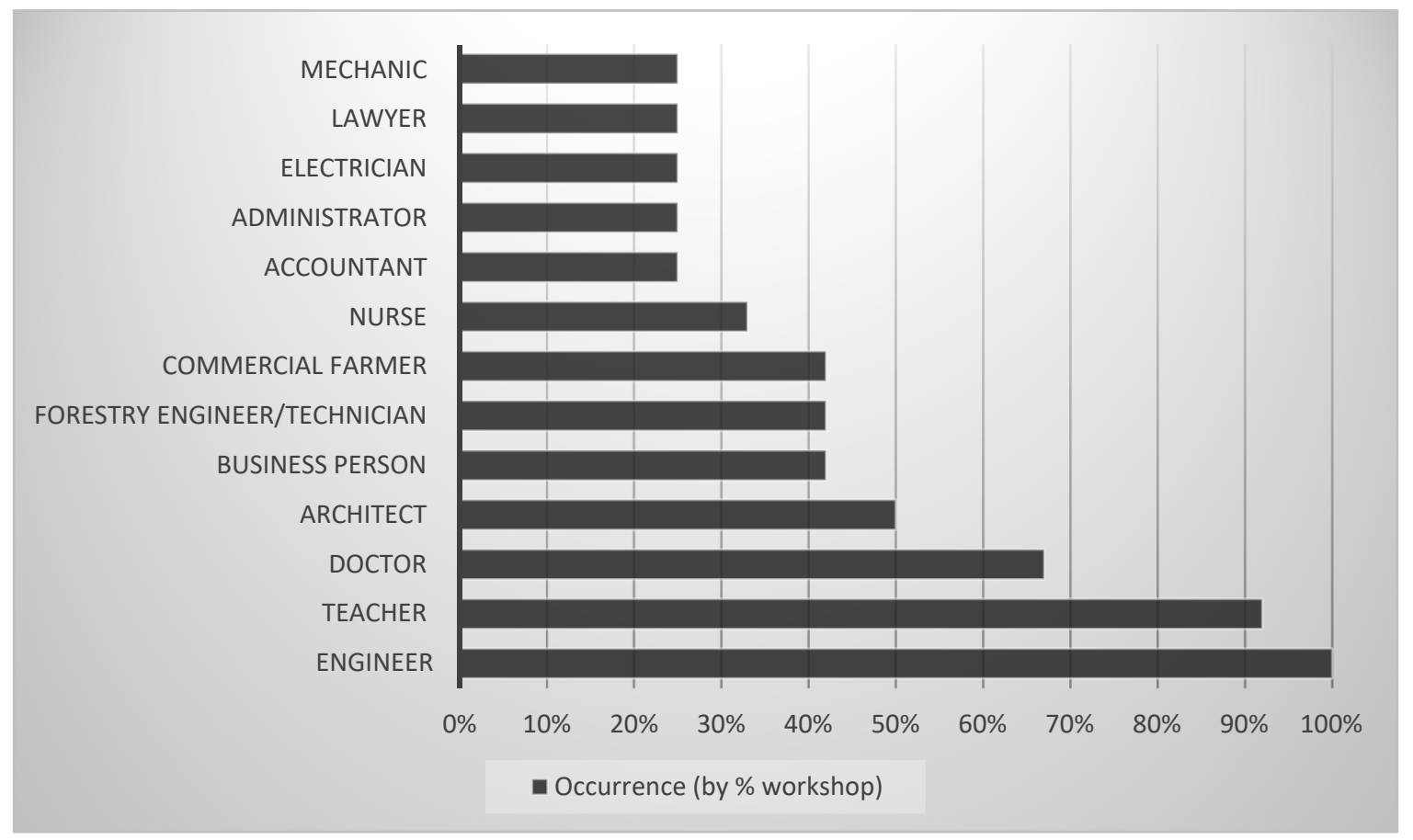

Figure 2. Most cited career options/choices (score of $100 \%$ indicates a career mentioned by at least one participant at all workshops).

Most youth were students at the time of participating in the research. Approximately half planned to pursue or complete tertiary education (Figure 3), while a third saw finishing high school as the limit of their aspirations. Of those pursuing further studies, a relatively small number considered technical college. More (39\%) aspired to university, with a quarter of these planning on a graduate degree (Masters or PhD). These findings indicate just how many youth are going onto higher education and the degree of access to high school and post-secondary institutions that make this possible. 


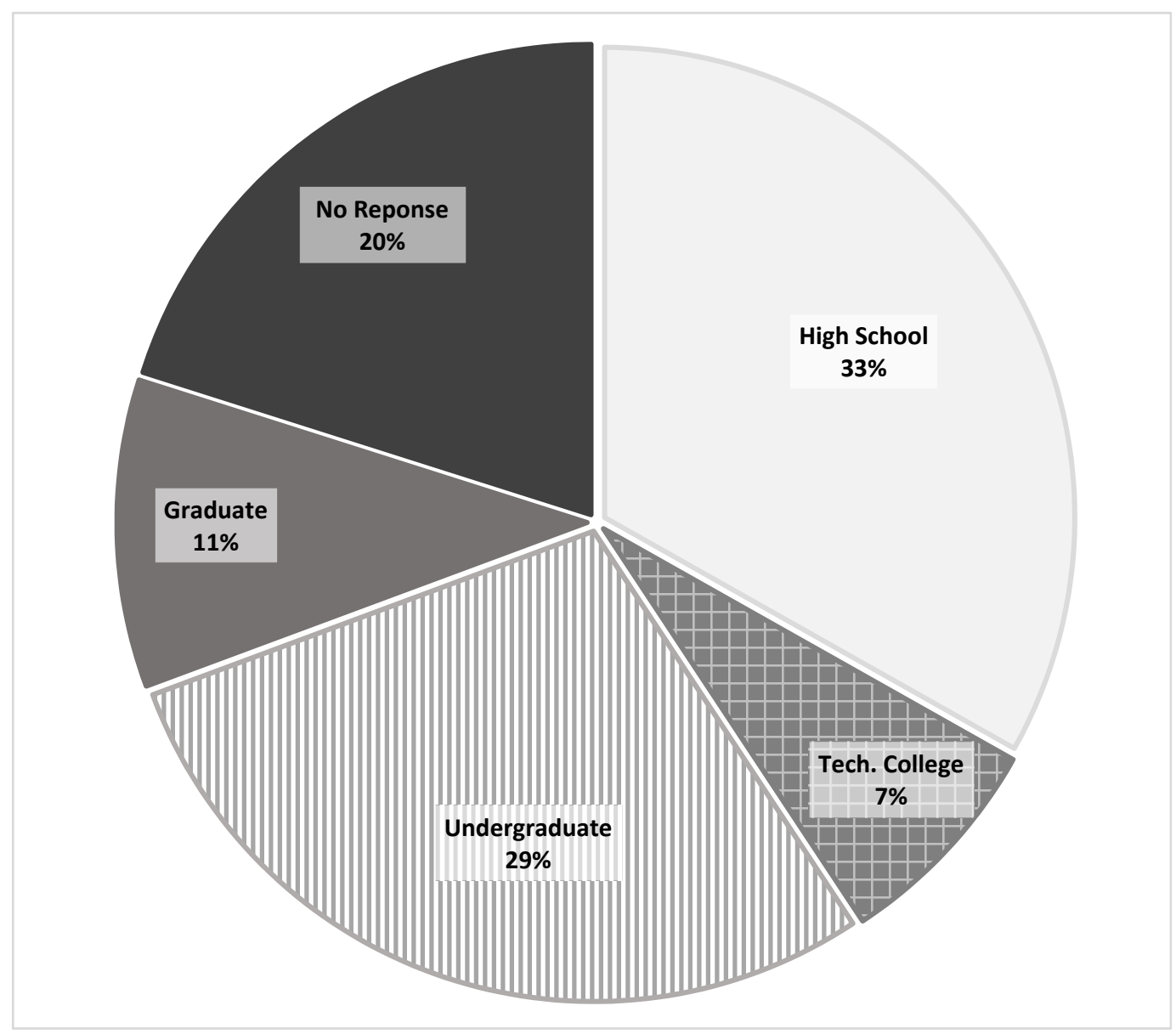

Figure 3. Educational aspirations of youth across workshop locations.

Only a small minority (7\%) of respondents across workshop locations expressed an interest in pursuing a land-based livelihood (Figure 4). Of these, over two-thirds cited family background and history ("to follow in my father's footsteps") as a reason why.

However, when we engaged participants in the "ideal jobs" workshop activity, differences with the survey data emerged. This was an activity where youth talked about what they would love to do work-wise, rather than what they were planning to do. Their responses were both more diverse and more specific than those from the questionnaires. Youth mentioned more jobs tied to culture and the arts, from dancer to Indigenous storyteller, making Indigenous crafts, and working with traditional foods and gastronomy. There was an increase in the number of IT-related and tourism-related jobs. In addition, with regards to natural-resource based work, these featured more prominently than in the survey data. Eleven individuals mentioned forestry engineer or some other forestry position, and another 8 youth cited jobs such as "owner of an ornamental plant nursery", "running a natural products business", and being "a Brazil nut exporter". A disproportionate number were participants in our Latin American workshops. Increased interest in forest-related work may have been influenced by participation in earlier workshop activities ("Show off your territory", "Let's talk about forests"). 


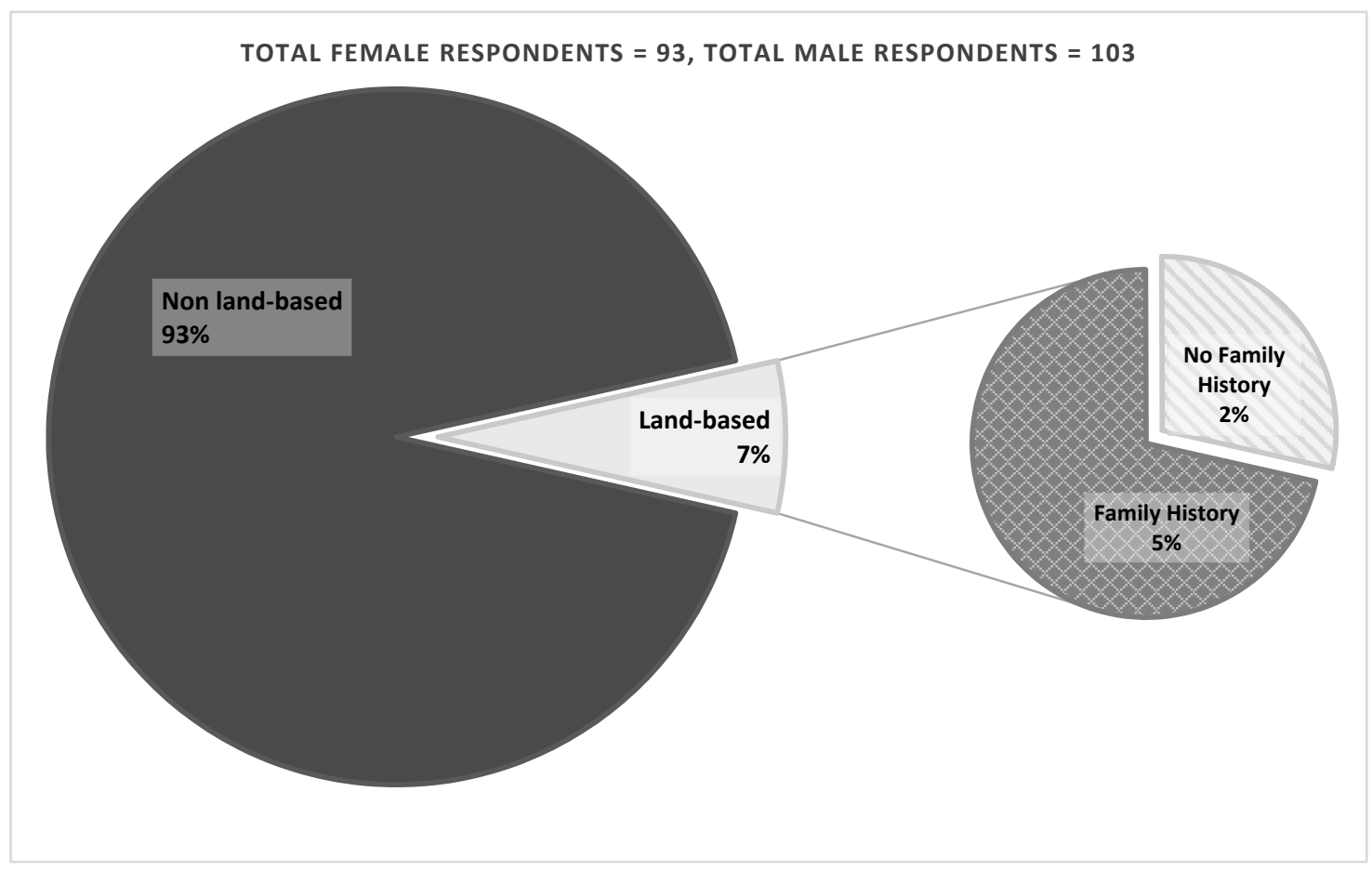

Figure 4. Youth-held plans to pursue land-based vs. non land-based livelihoods.

\subsection{Youth Mobility (Where Might Their Plans Take Them?)}

When youth were asked, "How likely are you to move away from your community?", 60\% of females and $54 \%$ of males said this was likely (Figure 5). A third of youth were unsure, and only a small minority (11-14\%) did not expect to leave. Geita (Tanzania), Buyege (Uganda) and El Puquio (Bolivia) stood out as locations with the highest probability of youth out-migration.

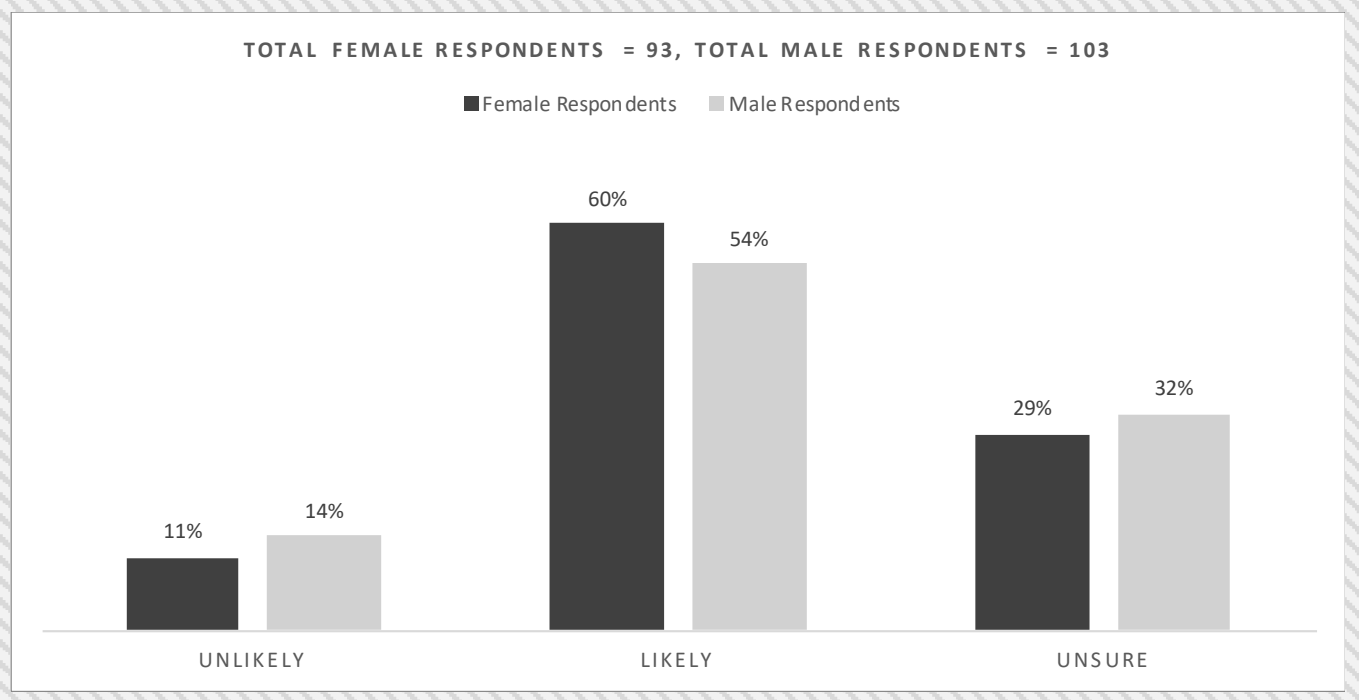

Figure 5. Likelihood that youth will move away from their community.

However, when asked, "Where would you like to be living when you are 30 years old?", a significant number of youth across workshops said that they hoped to be in their community (Figure 6), with Panauti (Nepal) and San Antonio (Bolivia) the stand outs. From a gender perspective, aggregate data did not point to any overriding trend, although females appeared more likely than males to migrate within their own country, and males more likely to participate in international migration. 


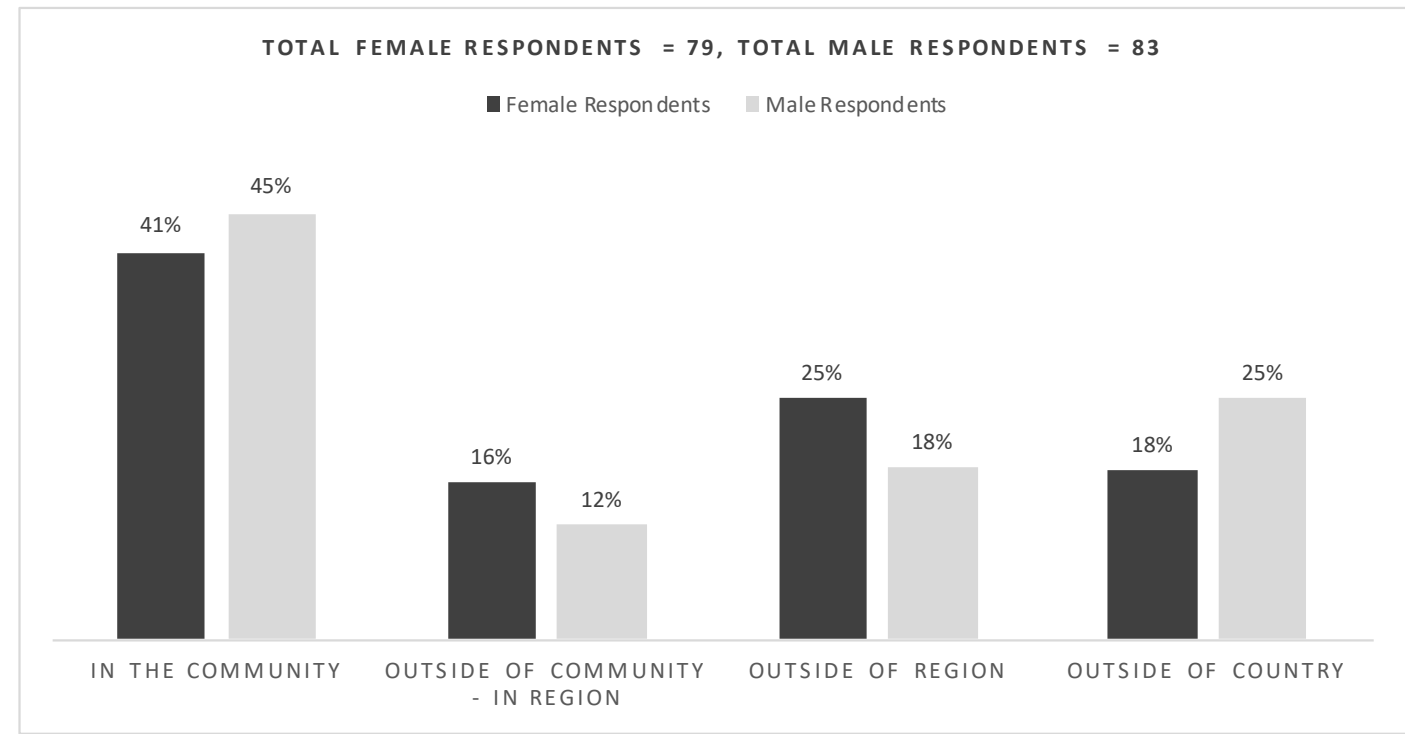

Figure 6. Where youth hope to be living when 30 years old.

These data suggest that while many youth envision life away from their community, some plan to do so on a temporary basis; to return at a later date. One interviewee from Analco was planning to return to the community once she started a family so that her children could grow up there-reflecting a widely-held perception that while cities offer job and study opportunities, life there can be hard and often dangerous.

It is also important to note that (while in the minority) every location had youth either not planning or wanting to leave their home community. Furthermore, when we conducted interviews with youth in Oaxaca (Phase 2 of the research), a third of youth we spoke to in Analco and half of those we spoke to in Jalapa del Valle expressed a desire to stay (if they could). Some were quite adamant: "The truth is that I don't want to continue studying. What I like to do is work in the fields and tend livestock ... since I was in sixth grade, my plan was not to study. Look, I never placed much importance on study ... I always focused more on work in the countryside" (Male, 29 years old, Analco)

\subsection{What Influences Youth Mobility Choices?}

In each visioning workshop, youth participated in "Push-Pull Matrix" and "Keep-Toss-Create" activities. These activities emphasised what youth liked (pull factors) and disliked (push factors) about their communities, and what they wanted to keep or to change. Summary findings are presented in Tables 2 and 3, respectively.

We observed synergy in responses across sites, with the lack of (well-paid) jobs, and limited access to education, health, and social services cited as key village push factors in most workshops and study regions. At the same time, youth valued cultural traditions and identity, and a strong environmental ethic - with stewardship of land, forest, and water all priorities-resonated across locations. Youth also valued their communities for providing a sense of security, peacefulness, and physical space when compared to the congested, noisy and contaminated cities they had experienced first-hand or heard about from friends and family. However, they also pointed to problems associated with living in a small, tight-knit and often conservative community setting-places where everyone knows each other's business. Youth in multiple locations talked about some variant of "parental control", "gossip", "jealousy", "egoism", "backstabbing", "discrimination" and "judgement" as things to rally against. Such complaints were often voiced most vociferously by female youth: "It's why we mentioned egoism ... you know we have this problem here of not allowing individuals to get ahead, to do well for themselves. We don't help each other enough." (Female, 27 years old, Mexico) 
Table 2. Push-Pull Matrix (aggregate results from 13 workshops analysed).

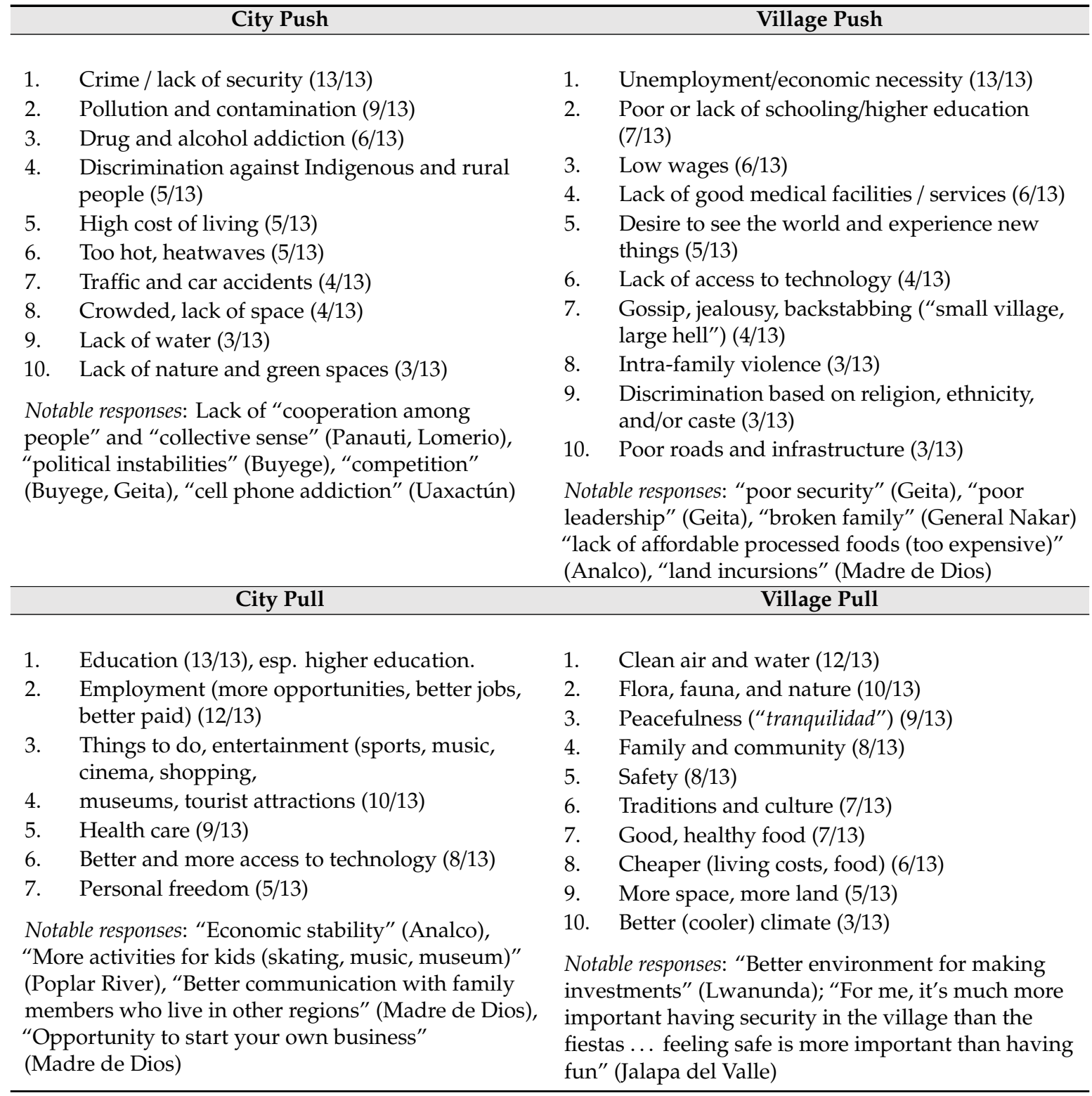

In contrast, youth across locations saw cities as places that could afford them greater liberty and opportunities for personal growth and development. In the Canadian, Mexican, Ugandan, and Filipino workshops, youth pointed to problems locally that emanate from deficient village governance-sometimes due to ineffective processes and at other times because of undemocratic structures and a lack of transparency that gave rise to abuses of power. Some youth felt under-represented in community decision-making, and felt that by being more involved they could help hold those in power accountable to the needs of the collective, and reduce corruption and the misuse of power and resources:

"I think they [Chief and Council] underestimate us as youth, our ideas and what will work...we are the next generation, we want to bring more" (Female youth, Poplar River FN, Canada) 
Table 3. What youth want to "Keep" and to "Toss" from their communities.

\begin{tabular}{|c|c|c|}
\hline Things to Keep & No. of Sites & Notes/Examples/Quotes \\
\hline $\begin{array}{l}\text { Cultural traditions and } \\
\text { practices }\end{array}$ & $9 / 13$ & $\begin{array}{l}\text { Municipal band (Analco); Patron saint festivities (Jalapa } \\
\text { del Valle, Analco); Tequio and community assemblies } \\
\text { (Analco); Native language (boys and girls, Analco; } \\
\text { Lomerio); Paati pauwa (resting place) (Panauti); Culture } \\
\text { and customs (Buyege); Traditional ways (Poplar River), } \\
\text { Ancestral knowledge (Madre de Dios) }\end{array}$ \\
\hline Forest stewardship & $7 / 13$ & $\begin{array}{l}\text { Forest management (boys, Analco; Uaxactún); Student } \\
\text { participation in reforestation activities (girls, Analco); } \\
\text { forest conservation and policy of not selling land to } \\
\text { outsiders (Jalapa del Valle); a healthy forest (Primero de } \\
\text { Mayo); Forest 'guarding' (Panauti) }\end{array}$ \\
\hline Care for nature and water & $7 / 13$ & $\begin{array}{l}\text { Respect for flora and fauna (Analco); Our care of the } \\
\text { river (Jalapa del Valle); Looking after wildlife and } \\
\text { drinking water source (Panauti); a clean stream (Primero } \\
\text { de mayo); clean water (Poplar River) }\end{array}$ \\
\hline Public services and facilities & $7 / 13$ & $\begin{array}{c}\text { Schools (Primero de Mayo, Analco, Lomerio, Lwanunda, } \\
\text { Buyege, General Nakar); Soccer field (San Antonio); } \\
\text { Health Centre, education (Lomerio); Hospitals, libraries } \\
\text { (Lwanunda); Family planning (Buyege) }\end{array}$ \\
\hline Traditional land practices & $4 / 13$ & $\begin{array}{l}\text { Agriculture and livestock practices (boys, Analco); Xate } \\
\text { Palm (Uaxactún); Agricultural services (Buyege); } \\
\text { swidden agriculture (General Nakar) }\end{array}$ \\
\hline Tings to toss & No. of sites & Notes/Examples/Quotes \\
\hline Drug/alcohol abuse & $8 / 13$ & $\begin{array}{c}\text { Drunks (Poplar River); the sale of alcohol to non-adults } \\
\text { (Primero de Mayo); Drugs (San Antonio); Alcoholism } \\
\text { (Puquio); Bars and Drinking Places, Gambling, Smoking } \\
\text { and Drug Abuse (Buyege); Drugs (General Nakar); } \\
\text { Marijuana abuse (Panauti) }\end{array}$ \\
\hline $\begin{array}{l}\text { Paternalistic, ineffective } \\
\text { governance }\end{array}$ & $6 / 13$ & $\begin{array}{c}\text { Chief and Council! (Poplar River); Corruption (San } \\
\text { Antonio); Dictatorship (Lwanunda); Corruption } \\
\text { (Buyege); Ineffective local governance (General Nakar); } \\
\text { unpaid cargos }{ }^{6} \text { (Jalapa del Valle) }\end{array}$ \\
\hline Social ills and discrimination & $5 / 13$ & $\begin{array}{l}\text { Egoism (girls, Analco); social discrimination rooted in } \\
\text { caste system (Panauti); pornography (online) } \\
\text { (Lwanunda); dowries (Panauti); machismo (San } \\
\text { Antonio); unregulated and excessive use of the Internet } \\
\text { (boys, Analco) }\end{array}$ \\
\hline $\begin{array}{l}\text { Litter, contamination in the } \\
\text { community }\end{array}$ & $6 / 13$ & $\begin{array}{l}\text { Burning of inorganic garbage (boys, Analco); trash (San } \\
\text { Antonio); contamination (Puquio); Garbage all over the } \\
\text { place (Poplar River, Madre de Dios); Plastic bags } \\
\text { (Lwanunda); Burning of garbage (General Nakar), }\end{array}$ \\
\hline $\begin{array}{l}\text { Deforestation, illegal logging } \\
\text { and/or hunting }\end{array}$ & $7 / 13$ & $\begin{array}{l}\text { Illegal hunting (boys, Analco; Panauti; Madre de Dios); } \\
\text { Illegal logging (San Antonio; General Nakar; Madre de } \\
\text { Dios); deforestation (Puquio; Uaxactún) }\end{array}$ \\
\hline Mining & $2 / 13$ & Specific issues in General Nakar and Madre de Dios \\
\hline
\end{tabular}

Youth insights from our Oaxaca study communities highlight how barriers to participation can incorporate an important gendered dimension:

6 A cargo is a local governance post or obligation that citizens must periodically serve in return for civic and communal membership and rights. 
"We think it's really important that we have much more balanced participation of men and women in the assemblies. In this community, nearly all the decisions are taken by men. The only way women participate is through doing cargos. And I have seen, I've been in assemblies, and I've seen how men dominate everything, even on the issues where women are well placed to contribute. An example is the community store, a place that women use much more than men, but we have had little say about how it should be run and maintained." (Female, 27 years old, Analco)

"With respect to what my compañera spoke about, it's true what she says. We have screwed things up in the past and often it's because the older men are not willing to listen to others' opinions ... when younger members have something they want to contribute, they either get laughed at or ignored. And it's something that turns us off and some don't want to participate anymore. So I'm in agreement with my compañera, when she says she would like to see more women involved, because it's the women that play such an important role in the community ... because women will often say that decisions that have been taken were not smart ones and this should have happened instead. They can help the community make better decisions and analyze why things don't work out as we want them to." (Male, 27 years old, Analco)

\subsection{Changes That Youth Want to See in Their Communities}

The "Keep-Toss-Create" activity provided an opportunity for youth to reflect upon and discuss the things that they wanted to see created or established in their communities (Table 4).

This long list can be divided into three broad thematic categories: environmental stewardship (education and conservation); village development (improved public services, communications, and jobs); and green economy (ecotourism, local food systems, conservation). Participants in nearly every workshop talked about the need for new environmental education and/or conservation programs, in addition to maintaining or creating formal protected areas and the importance of nature and green spaces. Youth wanted to see these promoted in their communities, along with training opportunities in forest management and conservation. Such insights highlighted the connection youth had with their community's lands. They care about local forests, water, and other territorial resources, and want to see conservation and sustainable rural development promoted locally. Additionally, access to health, education, and sporting services and facilities were important to youth in most workshops. More jobs, and more job-training opportunities, were hoped for (especially among youth at our Latin American and African workshops), along with improved access to digital communications. Such findings highlighted youth connections to other places, and the influence of urbanism and rural-urban linkages in particular. Desire for improved services/infrastructure was evident across sites and a reminder of what youth want to see in their communities and what they do not like about living there. When services are lacking, the city becomes a more attractive place to be. 
Table 4. What youth want to see in their communities (aggregate results from 13 workshops).

\begin{tabular}{|c|c|c|}
\hline Things to Create & No. of Sites & Notes/Examples/Quotes \\
\hline $\begin{array}{c}\text { Environmental } \\
\text { education/conservation }\end{array}$ & $10 / 13$ & $\begin{array}{l}\text { Training for young people in forest management and } \\
\text { conservation (Jalapa del Valle); Creation of an } \\
\text { Environmental Management Area (Unidad de Manejo } \\
\text { Ambiental) (girls, Analco); Communal forest } \\
\text { management plans (Madre de Dios); Environmental } \\
\text { education program (Madre de Dios); A system to control } \\
\text { and prevent fires (San Antonio); System to control water } \\
\text { contamination (Puquio); Greater awareness of } \\
\text { (consequences) of uncontrolled forest burning (Puquio); } \\
\text { Promotion of the “Guardians of the Woods" program } \\
\text { (Poplar River; Training for young people in forest } \\
\text { management and conservation (Jalapa del Valle); } \\
\text { Reforestation programs (Lomerio); Create parks, green } \\
\text { areas (Madre de Dios); More forests, trees (Buyege); } \\
\text { More PAs/biodiversity (Madre de Dios) }\end{array}$ \\
\hline Better cell/Internet & $4 / 13$ & $\begin{array}{l}\text { Free wifi (boys, Analco); Cell phone coverage (Jalapa del } \\
\text { Valle); Internet café (Lwanunda); Cell phone service } \\
\text { (Madre de Dios) }\end{array}$ \\
\hline Sporting facilities & $4 / 13$ & $\begin{array}{l}\text { Roof for the basketball court (Jalapa del Valle; General } \\
\text { Nakar); A stadium (Primero de Mayo); A soccer } \\
\text { academy (Lomerio); }\end{array}$ \\
\hline Education services & $4 / 13$ & $\begin{array}{l}\text { More pupils so we can maintain the schools (girls, } \\
\text { Analco); Support (scholarships) for students to increase } \\
\text { numbers in the schools (boys, Analco); A high school } \\
\text { (General Nakar); A school that provides the final } 3 \text { years } \\
\text { that lead up to high school (Uaxactún) }\end{array}$ \\
\hline Health services & $5 / 13$ & $\begin{array}{c}\text { Medicines for the health centre (boys, Analco); Better } \\
\text { medicines and equipment for the village health centre } \\
\text { (Jalapa del Valle); Better nurses (Poplar River); Hospital } \\
\text { equipment (Primero de Mayo); More health facilities } \\
\text { (Buyege) }\end{array}$ \\
\hline Jobs and job training & $7 / 13$ & $\begin{array}{l}\text { Better work opportunities (Jalapa del Valle); More } \\
\text { training in handicrafts (Uaxactún); Forge better } \\
\text { connection between school and the job market } \\
\text { (Lwanunda); For the Telesecundaria (secondary school } \\
\text { without in-person teaching) to add a course on carpentry } \\
\text { (Uaxactún); More jobs (Buyege) }\end{array}$ \\
\hline Better roads & $5 / 13$ & $\begin{array}{c}\text { Better roads (Poplar River; Lwanunda, Panauti); } \\
\text { Improved access to the community (Analco); Paved } \\
\text { roads (Jalapa del Valle); }\end{array}$ \\
\hline $\begin{array}{l}\text { Ecotourism/green } \\
\text { infrastructure }\end{array}$ & $4 / 13$ & $\begin{array}{c}\text { Eco-friendly housing (Popular River); More ecotourism } \\
\text { sites and centres (Jalapa del Valle); Promotion of } \\
\text { Latzi-Duu ecotourism (boys, Analco); Cycle Trail } \\
\text { (Panauti) }\end{array}$ \\
\hline $\begin{array}{c}\text { Food } \\
\text { production/greenhouses }\end{array}$ & $4 / 13$ & $\begin{array}{l}\text { Community greenhouse to produce vegetables (Primero } \\
\text { de Mayo); Greenhouse to grow orchids (San Antonio); } \\
\text { Greenhouse to grow citrus fruits (Puquio); Nursery } \\
\text { (Panauti); Orchid nursery (Analco) }\end{array}$ \\
\hline Local gastronomy & $3 / 13$ & $\begin{array}{l}\text { Elaborate new recipes and new products (Uaxactún); } \\
\text { Promote a gastronomy of regional products (Madre de } \\
\text { Dios); Elaborate products from cacao beans in the region } \\
\text { (Madre de Dios); Local organic market (girls, Analco) }\end{array}$ \\
\hline
\end{tabular}




\subsection{Nature of Youth-Territory-Forest Connections and Values}

Attachment to place was best reflected in the "Show off your territory" activity. Youth created a "tour itinerary" (a list of places to visit, and suggested route) in response to the question, what would you like to show youth from other communities about your community and forest? In some workshops, each participant selected one village and one non-village (territorial) "landmark" and jotted down the reasons for their choice (What does this place mean to you?). In other workshops, landmarks were suggested by means of a group discussion. In some cases, the same landmark was identified by multiple participants. In other cases, landmarks held specific, personal meanings to those who chose them. Youth "co-led" their tour of select landmarks, and in several cases, produced a physical map of landmarks and route.

Table 5 shows the diverse range of landmarks chosen and the most important or popular categories that they fell under.

Table 5. Categories of "landmarks" chosen by workshop participants. (aggregate across workshops).

\begin{tabular}{|c|c|}
\hline THEMATIC CATEGORIES & NO. OF LANDMARKS \\
\hline Nature and countryside & 51 \\
\hline Forests & 20 \\
\hline tree/plant & 10 \\
\hline forest & 5 \\
\hline natural area & 2 \\
\hline forestry infrastructure & 1 \\
\hline Indigenous culture and relationship with the forest & 1 \\
\hline tranquillity & 1 \\
\hline Landscapes and topography & 24 \\
\hline body of water & 14 \\
\hline viewpoint & 6 \\
\hline mountain & 2 \\
\hline caves & 1 \\
\hline natural disaster & 1 \\
\hline Farming and agriculture & 7 \\
\hline countryside & 2 \\
\hline farm/field & 5 \\
\hline Community infrastructure & 58 \\
\hline Commerce, industry, transportation & 9 \\
\hline store/market & 4 \\
\hline transit infrastructure & 3 \\
\hline factory & 1 \\
\hline tourist infrastructure & 1 \\
\hline Governance & 4 \\
\hline government office & 4 \\
\hline Health & 14 \\
\hline water infrastructure & 4 \\
\hline health facility & 3 \\
\hline Education & 7 \\
\hline school & 6 \\
\hline library & 1 \\
\hline Community life, culture, spiritual/religion & 29 \\
\hline music facility & 2 \\
\hline monument & 4 \\
\hline gathering spot & 3 \\
\hline religious place & 11 \\
\hline sports facility & 16 \\
\hline Basic needs & 2 \\
\hline residence & 2 \\
\hline
\end{tabular}


Village-specific landmarks covered a large range of types, with health-, recreation-, and sportingrelated landmarks among the most popular. Outside of their villages, several youths chose sites because of the views they afforded of their community's territory. As an Analco youth explained, "I find it really impressive that in this spot you have the coming together of three different communities and their territories. And besides, the view is amazing". Many chose landmarks that elicited memories of growing up or of family gatherings. About $20 \%$ of landmarks were forest-related.

When explaining their choices, forest sites were often chosen because of the environmental products and services that they provided (i.e., water, air, wood) or because of their solitude, their beauty, and the sense of communal pride they engender.

Forest values were further explored in the "Let's talk about forest" activity, where participants were asked to list and rank reasons why forests were important. Table 6 shows aggregate data to describe how forests were valued by youth for a diversity of environmental, spiritual, livelihood, and health reasons.

Environmental goods and services (provisioning and regulating services) were mentioned by a majority of participants in most workshops. Youth in a quarter of workshops mentioned the importance of forests for conserving mother nature/biodiversity. "Water (quality and quantity)" was a key benefit cited across a majority of workshops-youth perceived of a clear connection between water availability and good forest stewardship; talking at every workshop about the role that their forests play in "providing" or "purifying" the water that local people depend upon. This tied in with discussions during other workshop activities; clean drinking water had been among the most important benefits of village life (see Push-Pull Matrix), and a reason why youth may choose to stay in their communities. In contrast, water scarcity and water contamination were among key drawbacks associated with city life.

It was notable that youth in just one workshop included climate change mitigation as a major reason to conserve forests. In general, youth focused on the tangible, local benefits of their community forests. The "Show off your territory" activity highlighted this well, especially at the Latin American workshops: Primero de Mayo (Bolivia), where the Acai pulp processing plant was identified as a source of income for the community; Madre de Dios, Peru, where the chapaja palm tree (Attalea phalerata) was an important source of fibre, with "the palm leaves used to make roofs, brooms, and other things"; and, Uaxactun, Guatemala, where non-timber forest products such as xate palm, allspice and breadnut were included on territorial tours.

While forests were highly valued by youth across study sites and regions, youth-held knowledge of and frequency of interactions with forests (and the intentionality of these interactions) were less clear-cut and varied within and across sites. Workshop facilitators noted how youth who valued local forests often lacked specific knowledge about these forests (and the communal territory in more general terms). This was also evident during the "Show off your territory" activity, where selection of landmarks and tour itinerary tended to be dominated by a few knowledgeable, often older, participants. Lack of knowledge extended to forest management. In Jalapa, Mexico, for example, youth were not aware of current logging plans. When asked, "The assembly approved this [the forest plan], CONAFOR approved it, and now they are carrying out the study ... how many of you knew about [these developments]?", only 6 of 16 participants said that they did. As the group made clear, "they [the authorities] need to keep us informed!" In Guatemala, youth called for greater voice and involvement in forest governance-participating in the workshop was a catalyst for youth to self-organise and demand a voice in local governance structures [64]. A youth council was subsequently established. 
Table 6. The benefits of forests as identified by youth.

\begin{tabular}{|c|c|}
\hline Benefit & \% of Workshops \\
\hline \multicolumn{2}{|c|}{ Environmental Services/Regulation } \\
\hline Oxygen/ clean air & 100 \\
\hline Wildlife habitat & 86 \\
\hline Water (quality and quantity) & 71 \\
\hline Biodiversity & 29 \\
\hline Sustain life & 43 \\
\hline Soil & 29 \\
\hline Regulation & 21 \\
\hline Flora & 21 \\
\hline Agriculture & 21 \\
\hline Carbon sequestration & 21 \\
\hline Regulation & 21 \\
\hline Shade & 14 \\
\hline Windbreaks & 14 \\
\hline Natural disaster buffer & 14 \\
\hline Rain & 14 \\
\hline \multicolumn{2}{|c|}{ Work/Livelihoods/Employment } \\
\hline Work/Livelihoods & 86 \\
\hline Food & 50 \\
\hline Timber & 43 \\
\hline Tourism & 43 \\
\hline NTFPs (non-timber forest products) & 43 \\
\hline Hunting & 14 \\
\hline Housing & 14 \\
\hline Research & 14 \\
\hline \multicolumn{2}{|c|}{ Health and Wellbeing } \\
\hline Medicine & 43 \\
\hline Quality of life & 14 \\
\hline \multicolumn{2}{|c|}{ Tranquillity, Beauty, Nature } \\
\hline Beauty & 21 \\
\hline Peace and quietness & 14 \\
\hline Future generations & 14 \\
\hline Mother earth & 14 \\
\hline Landscape & 14 \\
\hline
\end{tabular}

\subsection{Youth Interest in Forestry and Forest-Related Work}

It was not entirely clear how many youth held a real interest in doing forest work. In the "ideal job" activity, 11 of 198 participants (most in Latin America) wanted to work in the forestry sector, so around 5\%. However, in the two study communities in Oaxaca, Mexico, 7 of 34 youth interviewed (so around 20\%) were either working in the forestry sector or had inclinations to do so. Yet, few could be specific about what they would like to do or were interested in. So, while forestry was seen as an option for some, it did not come across as an obvious livelihood opportunity or pathway for many. This was picked up on by a community leader in Oaxaca: "Right now, the community is growing, it is generating alternatives to be able to live within the community, and one of the great opportunities is thanks 
to the forest... we would like to have more young people, but there is little interest" (Common Property Commissioner, Analco).

Yet despite this, CF is still held out as a sector that offers opportunities to youth. Several of the academic, NGO, and government experts interviewed in Oaxaca saw $\mathrm{CF}$ as well placed to provide meaningful work to older youth-listing jobs in reforestation, pest control, environmental education, ecotourism, agave management, oak charcoal production, copal management, non-timber forest products (palms, resins, mushrooms), logging, and marketing, among others. A sentiment echoed by a community leader in Jalapa del Valle: "It is very important for us, that we have a large area of forest, and we have the need for technical advice, that young people get training in this and take a lead" (Common Property Commissioner, Jalapa).

Additionally, while knowledge about forests and forest management appeared limited among youth, across locations there was a number of participants keen to share their forestry perspectives and ideas. For example, while youth promoted a strong conservationist ethic during workshop activities and discussions, most saw sustainable forest use as being compatible with conservation and to be promoted as a necessary part of community modernisation and development. In our final workshop activity-"Co-Design: Pilot Project"—youth highlighted how they might contribute if brought more into the fold. In small groups, they developed ideas for work-related projects or initiatives in their community that were land and/or forest based. Their ideas fell into five main categories-Education/Ecotourism; Agroforestry and NTFPs; Wood and Fibre Extraction; Forests and Water; and Agriculture and Animal Husbandry—and ranged from modest endeavours, such as a “Community vegetable garden" (Lomerio, Bolivia), to larger scale proposals such as a "Youth-run ecotourism centre" (Jalapa, Mexico). Water was a notable focus, including a community water bottling plants (Nepal, Mexico, Bolivia), irrigation infrastructure (Bolivia), and a water purification system (Canada). While some groups spent considerable effort developing actual business plans, other ideas remained more conceptual in nature.

Youth interest in CF and forest-related work was also evident in Phase 2 fieldwork in Oaxaca, where, again, a small but significant minority of participants spoke enthusiastically about their forest work experiences to date and their willingness to embrace further opportunities:

"Yes, I would like to get more involved because it is nice, in fact, there was a time when they [local
authorities] gave temporary employment, and I went when I was on vacation. And it was to go to take
care of the small pines that grow on their own, to clean around them so they could continue growing.
Then also pruning and all that ... and I liked to go then yes, I would like to continue doing that"
(Female, 20 years old, Analco)

"Especially for women, we were very motivated because we felt very useful, right?... The men are used to going to the mountains to attend the tequios ${ }^{7}$, so for them it is no big deal. In the case of women, it was like something was really motivating us to keep going. We did not want the job to end because apart from feeling useful, it was paid and so we could contribute to the household. So women were the ones who were always there ready and on time. I mean, if they told us at 5:30, we were waiting for the bus at 5:20". (Female, 28 years old, Analco)

\section{Discussion}

Rural, resource-dependent communities in Mexico, Latin America, and other regions have been identified as critical actors in global conservation efforts [1,65]. Yet, community forests and other local resource commons exist in a world undergoing accelerated processes of change [66], and their evolution in response to change remains understudied by theorists $[55,67,68]$.

7 Tequios are obligatory labour days levied on adult able-bodied men and, more recently, women to carry out projects in their community. 
The experience of migration is pervasive in many rural areas, and can reframe the idea of future livelihood [69] to give less and less weight to the territory, lands, and natural resource practices of local communities. Within such a context of rural change and de-territorialisation, the actual and prospective roles for youth in rural community development are important $[63,70,71]$. Not least to communities themselves, who understand that the energy, talent, and leadership that young people can bring to the table [72] are assets of great value, not least in places where out-migration has created shortfalls in collective labour [62,73].

In places where forests are used and managed by local communities, the choices of young people are no less significant [21,74]. Faced with limited opportunities where they live, and the allure of work and education possibilities elsewhere, the global trend has been one of people leaving their forest communities, often for cities and other urban centres [11,12]. However, is the emptying out of forest regions inevitable in an era of globalisation and globalised change? With this research, we wanted to better understand the views, values, and hopes of young people from forest communities, to understand forests and community forestry through their eyes, and reflect on the possibilities for forest-based economies that meet their aspirations for meaningful work-and a good life. Through exploring youth culture in forest communities in Asia, Africa, and the Americas, the work delivers six big findings:

1. Youth value and hold strong connections to their communities. They especially value their communities for the physical space, healthy (natural) environment, and traditions they provide.

2. The strong values that youths hold do not translate into plans to remain in their communities and pursue land-based livelihoods. Work and study aspirations mean that migration (whether temporary or permanent) is on the cards for most.

3. Across the board, youth out-migration is strongly influenced by job and/or educational aspirations and opportunities. Parental control, village gossip, jealousy, egoism, discrimination and antiquated communal service practices were additional push factors identified in some communities.

4. Youth can feel left out of community-level decision-making processes, with village governance arrangements not inclusive of broad community memberships (and which can be further exacerbated by patriarchal cultural norms). Feelings of under-representation are more evident among female than male youth. However, such concerns or criticisms do not appear to be an influencing factor behind youth-held mobility plans.

5. While many youth plan to leave their communities for study, work and/or life experiences, significant numbers expect/plan/hope to return. Similarly, most study communities have a sizeable minority of resident youth who would like to stay if opportunities allow.

6. Most youth do not consider community forestry as an obvious livelihood pathway. However, youth do value the natural environment and forests, and see sustainable forest management as an important part of community development and advancement.

We found that local forests remain important to some youth in all of the communities where we worked. Their own reliance or dependence on forests and associated resources might be limited, but forests are valued by youth who understand their importance for cultural or spiritual reasons, for the ecosystem services that they provide; and, the direct livelihood benefits that they generate.

Moreover, in each workshop and place we worked, we came across youth with a real sense of connection and commitment to their community that local leaders could be well served to build upon. Yet, engaging and empowering youth will involve more than simply creating opportunities and waiting for youth to respond. Communities must first take the time to listen to and understand youth, who are not inward-looking but very much connected to realities that lie outside of their home communities. This was evident in our discussions with youth about their work and study aspirations, and their views on community vs. city life. In looking to express identity and subjectivity [69], youth meld their own cultural heritage with the influence of dominant, urban society [72]. In other 
words, a multitude of factors and perspectives can (and will) shape the choices and decisions that youth make, and subsequently their propensity (or not) to invest in their communities despite the chance to engage the global market through migration $[75,76]$.

What might this mean for the community forestry sector in different global regions? A few years ago, the anthropologist, Norman Schwartz, remarked: "It does appear that most youngsters no longer want to live with/in the forests the way their parents did. However, we may be looking at the situation from the wrong angle, since there are youngsters who want to co-exist with forests on their terms, rather than ours". He was making the point that communities need to engage their youth in open and honest conversations before thinking through policies and initiatives designed to successfully involve young people in forestry and forest work. Our work supports such a view, and not only in the context of CF but environmental governance and stewardship more broadly [38,48,77].

In addition, while the need to better engage, involve, and empower youth in such activities is becoming clear [78-80], capacities to do so can be limited or constrained (see [38,81,82]). While some youth may be keen to act upon (perceived) stewardship responsibilities, they face barriers to do so $[74,83]$. Some of the most significant are tied to existing cultural norms and institutions, often entrenched [83], and not always representative or inclusive of distributions of identity, power, and privilege across community memberships [53,84]. Work in Mexico, Guatemala, and Peru has already shown us that efforts to engage youth can be a catalyst for organisational and institutional renewal $[64,77,85]$. However, this may not be a universal outcome, with insights from other places showing us how resistant to change community norms and institutions can be [52].

In considering new ways for youth to be involved in community activities, collectives will necessarily enter a process of internal negotiation, through which they try to create forms of "service" and engagement in which members can participate, and exercise citizenship, regardless of where they live, how old they are, or the status that they hold. In this way, communities are challenged to develop a set of internal normative structures that can provide meaning (and sense of representation) across member profiles, including young people. Oaxaca, Mexico, provides an interesting case in point, where departure from a strict custom of non-remunerated communal service has been controversial-altering as it does a long-standing social contract between members and their community-yet perhaps inevitable once a critical mass of community members become open to "other kinds of being" [see 84]. In the two study communities from Oaxaca, a majority of older youth complained about having to meet (unpaid) cargo and tequio responsibilities. It left several feeling conflicted. While the carrying out of such roles constitute a service to the home community that they value, the impact on individual and family livelihoods and wellbeing is often adverse: "Being a community member implies many responsibilities across community life. If they give us a service to do, we have to fulfil it, and we have to make tequios and attend assemblies. So sometimes, for a young person, it is not that the work is complicated, but it's hard to fit everything in ... I am single, and it could be seen as an advantage because I have time to participate, but at the same time to have so many responsibilities ... it's complicated" (Female, 28 years old, Analco).

What is clear is that creating the space and opportunities needed for youth to flourish within their home communities will not be a quick, overnight process. The cultural norms that dictate how people are viewed and treated by others, and incorporated into community life, do not change easily [86]. Similarly, efforts to engage youth in CF and other community-based initiatives should not be promoted solely from the perspective of halting youth out-migration or to discourage youth from leaving. Rather, we believe that it is about keeping youth connected to their places of origin, irrespective of whether they remain rural residents, opt for life in the city, or leave with a plan to return "home" in the future. Migration can drive change with the potential to transform rural, resource-dependent communities [61,87], yet as a social phenomenon it expands the boundaries or social field of sending communities as migrants create linkages back to their communities $[12,76,84,88]$. Thus, rather than having to "decommonise" [67] under the pressures of demographic and social change, communities do have the wherewithal to reconstruct local governance and craft new institutions for upwardly mobile 
memberships [89,90]; not least youth, whose decision-making is shaped by varied and often complex motivations and aspirations $[52,91]$.

\section{Conclusions}

It has been argued that local and Indigenous communities be given a leading role in environmental governance as societies strive for more sustainable futures [81]. However, as rural populations undergo demographic transitions, questions remain as to the ability of such communities to perform this role. In particular, will enough young people remain active players in community- and territorymaking processes?

In the context of community forestry, the loss of young people (whether through out-migration or because of limited interest in land-based livelihoods) poses a multidimensional challenge to communities and the organisations that support them, and suggests that youth engagement and empowerment may be critical to building sustainable CF futures. Yet, CF scholars, practitioners, and donors have paid limited attention to youth-community-forest connections, including whether current structures reflect the personal, professional, and shared aspirations of young people and offer the kind of meaningful opportunities that they will take up. The research presented here contributes to addressing this knowledge gap.

Across Asia, Africa, and the Americas, we found that while some differences emerged, there was notable synergy across sites. Despite strong connections to their home communities, we found that a majority of youth do envision their futures, at least for a time, away from the home village-as they look to meet aspirations not always well matched with the current realities of community life and economy, including those tied to forests. However, a minority of youth in most locations do want or plan to stay, and a significant number are keen to settle long-term in their communities (if opportunities allow). This suggests that a mass exodus of youth is by no means inevitable, and offers communities hope for the future.

Yet as community leaders and CF practitioners propose forest- and land-based work as an engine of local development, our work casts doubt on the assumption that a promise of forest jobs will keep young people from leaving or encourage more to return. Rather, the research suggests that communities first need to reach out to youth to better understand their motivations, expectations, and ideas. Well-developed approaches, such as participatory action research and adaptive collaborative management [92,93], offer pointers as to how this might be done. If opportunities can be identified (and then developed) that reflect youth-held aspirations, and local institutions adapted to incentivise and empower youth to take on active and significant roles in village, community and territorial life, then more youth will be enticed to stay or return and to become true "agents of change" [33] in the places that they still call "home".

Supplementary Materials: The following are available online at http://www.mdpi.com/2073-445X/9/11/406/s1, Table S1: Overview of Main Workshop Activities; Table S2: Participant Questionnaire; Table S3: Key Background Information on Workshop Locations and Participating Communities.

Author Contributions: Conceptualisation, J.P.R., S.J.W., and C.M.S.; methodology, J.P.R. and C.M.S.; validation, J.P.R. and C.M.S.; formal analysis, J.P.R., S.J.W. and C.M.S.; investigation, J.P.R. and C.M.S.; writing-original draft preparation, J.P.R., S.J.W., and A.B.; writing-review and editing, J.P.R. and A.B.; visualisation, J.P.R. and A.B.; supervision, J.P.R. and S.J.W.; project administration, J.P.R. and S.J.W.; funding acquisition, J.P.R. and S.J.W. Authorship is limited to those who have contributed substantially to the work reported. All authors have read and agreed to the published version of the manuscript.

Funding: Phase 1 research (youth visioning workshops and synthesis meeting) was made possible due to funding from the Social Sciences and Humanities Research Council (SSHRC) (Connection Grant, \# 611-2016-0262), and the Ford Foundation (grant administered by the Institute of International Education, under activity \# CNV3252010/FF12H10). Phase 2 research was made possible due to funding from the Social Sciences and Humanities Research Council (SSHRC) (Insight Development Grant, \# 430-2018-00007).

Acknowledgments: We thank all the young people who participated in the visioning workshops, as well as the community and non-governmental organisations and authorities who assisted in their organisation and hosting. We thank colleagues (in no particular order) for their help in workshop design, workshop facilitation, 
literature searches, assistance in the field, and professional insights: Iain Davidson-Hunt, Shashank Kumar, Scott Francisco, Fermin Sosa Perez, Michelle Sanchez Luja, Marlene Soriano, Julia Quaedvlieg, Iliana Monterroso, Julio Zetina, Miriam Castillo, Birendra Karna, Leigh Fox, Hugo Asselin, David Bray, Dan Klooster, Yolanda Lara, Francisco Chapela, Maria Paula Sarigumba, Maureen Reed, and Melissa (Missy) Rice. We thank the University of Saskatchewan, Canada, for hosting a synthesis meeting involving the research team and collaborators in August 2018. Lastly, we thank FLARE (Forests \& Livelihoods: Assessment, Research, and Engagement) (www.forestlivelihoods.org). The impetus for this work followed discussions by FLARE's 'The Future of Forest Work and Communities' Working Group in 2016 and 2017.

Conflicts of Interest: The authors declare no conflict of interest. The funders had no role in the design of the study; in the collection, analyses, or interpretation of data; in the writing of the manuscript, or in the decision to publish the results.

\section{References}

1. Boillat, S.; Scarpa, F.M.; Robson, J.P.; Gasparri, I.; Aide, T.M.; Aguiar, A.P.D.; Anderson, L.O.; Batistella, M.; Fonseca, M.G.; Futemma, C.; et al. Land system science in Latin America: Challenges and perspectives. Curr. Opin. Environ. Sustain. 2017, 26, 37-46. [CrossRef]

2. Rights and Resources Initiative. Securing Community Land Rights: Priorities \& Opportunities to Advance Climate \& Sustainable Development Goals. 2017. Available online: https:/rightsandresources.org/en/ publication/securing-community-land-rights-rri-brief/\#.Wk40a1cSCf0 (accessed on 15 September 2020).

3. Rights and Resources Initiative. Secure Indigenous Peoples and Community Land Rights as a Nature-Based Solution to Climate Change. In UN Secretary General Climate Action Summit; Rights and Resources Initiative: Washington, DC, USA, 2019.

4. Gray, E.; Veit, P.; Altamirano, J.-C.; Ding, H.; Rozwalka, P.; Zúñiga, I.; Witkin, M.; Borger, F.G.; Lucchesi, A.; Carvalho Pereda, P.; et al. The Economic Costs and Benefits of Securing Community Forest Tenure Evidence from Brazil and Guatemala; World Resources Institute: Washington, DC, USA, 2015.

5. Persha, L.; Agrawal, A.; Chhatre, A. Social and ecological synergy: Local rulemaking, forest livelihoods, and biodiversity conservation. Science 2011, 331, 1606-1608. [CrossRef]

6. Porter-Bolland, L.; Ellis, E.A.; Guariguata, M.R.; Ruiz-Mallén, I.; Negrete-Yankelevich, S.; Reyes-García, V. Community managed forests and forest protected areas: An assessment of their conservation effectiveness across the tropics. For. Ecol. Manag. 2012, 268, 6-17. [CrossRef]

7. Angelsen, A.; Jagger, P.; Babigumira, R.; Belcher, B.; Hogarth, N.J.; Bauch, S.; Wunder, S. Environmental income and rural livelihoods: A global-comparative analysis. World Dev. 2014, 64, S12-S28. [CrossRef] [PubMed]

8. Baynes, J.; Herbohn, J.; Smith, C.; Fisher, R.; Bray, D. Key factors which influence the success of community forestry in developing countries. Glob. Environ. Chang. 2015, 35, 226-238. [CrossRef]

9. Charnley, S.; Poe, M.R. Community forestry in theory and practice: Where are we now? Ann. Rev. Anthropol. 2007, 36, 301. [CrossRef]

10. Bray, D.B.; Duran, E.; Ramos, V.H.; Mas, J.F.; Velazquez, A.; McNab, R.B.; Barry, D.; Radachowsky, J. Tropical deforestation, community forests, and protected areas in the Maya Forest. Ecol. Soc. 2008, 13, 18. [CrossRef]

11. Hecht, S.B.; Yang, A.L.; Basnett, B.S.; Padoch, C.; Peluso, N.L. People in Motion, Forests in Transition: Trends in Migration, Urbanization, and Remittances and Their Effects on Tropical Forests; Centre for International Forestry Research (CIFOR); Indigenous and Northern Affairs Canada (INAC): Bogor, Indonesia, 2015; Volume 142.

12. Robson, J.P.; Klooster, D.; Hernández-Díaz, J. Communities Surviving Migration: Village Governance, Environment, and Cultural Survival in Indigenous Mexico; Routledge/Earthscan: Abingdon, UK, 2019.

13. Berdegué, J.A.; Bebbington, A.J.; Rosada, T. The rural transformation. In International Development: Ideas, Experience, and Prospects; Currie-Alder, B., Kanbur, R., Malone, D.M., Medhora, R., Eds.; Oxford University Press: Oxford, UK, 2014.

14. Fairbairn, M.; Fox, J.; Isakson, S.R.; Levien, M.; Peluso, N.; Razavi, S.; Scoones, I.; Sivaramakrishnan, K. Introduction: New directions in agrarian political economy. J. Peas. Stud. 2014, 41, 653-666. [CrossRef]

15. Kay, C. The agrarian question and the neoliberal rural transformation in Latin America. Eur. Rev. Latin Am. Carib. Stud. 2015, 73-83. [CrossRef]

16. Kay, C. Reflections on Latin American rural studies in the neoliberal globalization period: A new rurality? Dev. Chang. 2008, 39, 915-943. [CrossRef] 
17. Haggblade, S.; Hazell, P.B.; Reardon, T. (Eds.) Transforming the Rural Nonfarm Economy: Opportunities and Threats in the Developing World; International Food Policy Research Institute: Washington, DC, USA, 2007.

18. United Nations; Department of Economic and Social Affairs; Population Division. World Population Prospects: The 2017 Revision, Key Findings and Advance Tables; Working Paper No. ESA/P/WP/248; United Nations: New York, NY, USA, 2017.

19. Anríquez, G.; Stloukal, L. Rural population change in developing countries: Lessons for policymaking. Eur. View 2008, 7, 309-317. [CrossRef]

20. Chhatre, A.; Agrawal, A. Forest commons and local enforcement. Proc. Natl. Acad. Sci. USA 2008, 105, 13286-13291. [CrossRef]

21. Macqueen, D.; Campbell, J. Prosperity in Place: Meaningful Work for Mobile Youth that Enhances Forest Landscapes; FAO and IIED: London, UK, 2020.

22. Kluve, J.; Puerto, S.; Robalino, D.; Romero, J.M.; Rother, F.; Stöterau, J.; Weidenkaff, F.; Witte, M. Interventions to improve the labour market outcomes of youth: A systematic review of training, entrepreneurship promotion, employment services, and subsidized employment interventions. Campbell Syst. Rev. 2017, 12, 1-288.

23. Antinori, C.; Bray, D.B. Community forest enterprises as entrepreneurial firms: Economic and institutional perspectives from Mexico. World Dev. 2005, 33, 1529-1543. [CrossRef]

24. Klooster, D.; Taravella, R.; Hodgdon, B.D. Striking the Balance: Adapting Community Forest Enterprise to Meet Market Demands. A Case Study of TIP Muebles (Oaxaca, Mexico); Community Forest Case Studies 7/10; Rainforest Alliance: Washington, DC, USA, 2015.

25. Hajjar, R.; Oldekop, J.A.; Cronkleton, P.; Etue, E.; Newton, P.; Russel, A.; Agrawal, A. The data not collected on community forestry. Conserv. Biol. 2016, 30, 1357-1362. [CrossRef] [PubMed]

26. Martínez-Bautista, H.; Zamudio Sánchez, F.J.; Alvarado-Segura, A.A.; Ramírez Maldonado, H.; Fuentes Salinas, M. Factores que determinan el éxito o fracaso de proyectos forestales comunitarios con financiamiento gubernamental en México. Bosque Valdivia 2015, 36, 363-374. [CrossRef]

27. Evans, K.; Flores, S.; Larson, A.M. Participatory Monitoring in Forest Communities to Improve Governance, Accountability and Women's Participation. Small-Scale For. 2019, 18, 165-187. [CrossRef]

28. Sunderland, T.; Achdiawan, R.; Angelsen, A.; Babigumira, R.; Ickowitz, A.; Paumgarten, F.; Shively, G. Challenging perceptions about men, women, and forest product use: A global comparative study. World Dev. 2014, 64, S56-S66. [CrossRef]

29. Quaedvlieg, J. Las Relaciones de Género y el Role de la Mujer en el Desarrollo Socio Ambiental de Madre de Dios; Consorcio Madre de Dios: Madre de Dios, Peru, 2015; Unpublished Report.

30. Cleaver, F. Development through Bricolage: Rethinking Institutions for Natural Resource Management; Routledge: London, UK, 2017.

31. Asher, K.; Varley, G. Gender in the jungle: A critical assessment of women and gender in current (2014-2016) forestry research. Inter. For. Rev. 2018, 20, 149-159. [CrossRef]

32. Lastarria-Cornhiel, S.; Behrman, J.A.; Meinzen-Dick, R.; Quisumbing, A.R. Gender equity and land: Toward secure and effective access for rural women. In Gender in Agriculture; Springer: Dordrecht, The Netherlands, 2014; pp. 117-144.

33. Ginwright, S.; James, T. From assets to agents of change: Social justice, organizing, and youth development. New Dir. Youth Dev. 2002, 96, 27-46. [CrossRef]

34. McCune, N.; Rosset, P.M.; Cruz Salazar, T.; Morales, H.; Saldívar Moreno, A. The long road: Rural youth, farming and agroecological formación in Central America. Mind Cult. Act. 2017, 24, 183-198. [CrossRef]

35. White, B. Generational dynamics in agriculture: Reflections on rural youth and farming futures. Cah. Agric. 2015, 24, 330-334. [CrossRef]

36. MacDonald, J.P.; Harper, S.L.; Cunsolo Willox, A.; Edge, V.L.; Rigolet Inuit Community Government. A necessary voice: Climate change and lived experiences of youth in Rigolet, Nunatsiavut, Canada. Glob. Environ. Chang. 2013, 23, 360-371. [CrossRef]

37. Smith, J.G.; DuBois, B.; Krasny, M.E. Framing for resilience through social learning impacts of environmental stewardship on youth in post-disturbance communities. Sustain Sci. 2016, 11, 441-453. [CrossRef]

38. Zurba, M.; Trimble, M. Youth as the inheritors of collaboration: Crises and factors that influence participation of the next generation in natural resource management. Environ. Sci. Policy 2014, 42, 78-87. [CrossRef] 
39. Macneil, C.; Brown, H.C.P.; Sonwa, D.J. Investigations of the livelihood strategies of young men and women in forested landscapes of eastern Cameroon. Int. For. Rev. 2017, 19, 437-448.

40. Browne, L.P.; Garst, B.A.; Bialeschki, D. Engaging youth in environmental sustainability: Impact of Camp 2 Grow Program. J. Park Recreat. Adm. 2011, 29, 70-85.

41. Nursey-Bray, M.; Palmer, R. Country, climate change adaptation and colonisation: Insights from an Indigenous adaptation planning process, Australia. Heliyon 2018, 4, e00565. [CrossRef]

42. Marquardt, K.; Pain, A.; Ojha, H. Shifting regimes of management and uses of forests: What might REDD+ implementation mean for community forestry? Evidence from Nepal. For. Pol. Econ. 2018, 92, 1-10.

43. Newton, P.; Schaap, B.; Fournier, M.; Cornwall, M.; Rosenbach, D.W.; DeBoer, J.; Agrawal, A. Community forest management and REDD+. For. Pol. Econ. 2015, 56, 27-37. [CrossRef]

44. Bayrak, M.M.; Marafa, L.M. REDD+ as a Vehicle for Community-Based Forest Management? Critical Insights from Vietnam. Small-Scale For. 2020, 19, 57-81. [CrossRef]

45. Robson, J.P.; Klooster, D.J. Migration and a new landscape of forest use and conservation. Environ. Cons. 2019, 46, 1-8. [CrossRef]

46. Aquino-Moreschi, A.; Contreras-Pastrana, I. Community, young people and generation: Contesting subjectivities in the Sierra Norte de Oaxaca. Latin Am. J. Soc. Sci. Child. Youth 2016, 14, 463-475.

47. Howitt, R. Sustainable indigenous futures in remote Indigenous areas: Relationships, processes and failed state approaches. GeoJournal 2012, 77, 817-828. [CrossRef]

48. Clendenning, J. Approaching Rural Young People; CIFOR: Bogor, Indonesia, 2019; Volume 1.

49. Bray, D.B.; Merino-Pérez, L.; Negreros-Castillo, P.; Segura-Warnholtz, G.; Torres-Rojo, J.M.; Vester, H.F. Mexico's community-managed forests as a global model for sustainable landscapes. Conserv. Biol. 2003, 17, 672-677. [CrossRef]

50. Trivelli, C.; Morel, J. Rural youth inclusion, empowerment and participation. J. Develop. Stud. 2019. [CrossRef]

51. Theodori, A.E.; Theodori, G.L. Perceptions of community and place and the migration intentions of at-risk youth in rural areas. J. Rural Soc. Sci. 2014, 29, 5.

52. Robson, J.P.; Wilson, S.J.; Francisco, S.; Rice, M. The Future of Forest Work and Communities: Learning from Youth Engagement Workshops in Asia, Africa, and the Americas; University of Saskatchewan: Saskatoon, SK, Canada, 2019; Unpublished Report.

53. Baker, M.J. The Kuhls of Kangra: Community-Managed Irrigation in the Western Himalaya; University of Washington Press: Seattle, WA, USA; London, UK, 2005.

54. Klooster, D. The impact of transnational migration on commons management among Mexican Indigenous Communities. J. Lat. Am. Geogr. 2013, 12, 57-86. [CrossRef]

55. Ostrom, E.; Ahn, T.K. The meaning of social capital and its link to collective action. In Handbook of Social Capital: The Troika of Sociology, Political Science and Economics; Edward Elgar: Northampton, MA, USA, 2009; pp. 17-35.

56. Huber, M.S.Q.; Frommeyer, J.; Weisenbach, A.; Sazama, J. Giving youth a voice in their own community and personal development. In Community Youth Development; Sage: Thousand Oaks, CA, USA, 2003; pp. $297-323$.

57. Zeldin, S.; Christens, B.D.; Powers, J.L. The psychology and practice of youth-adult partnership: Bridging generations for youth development and community change. Am. J. Community Psychol. 2013, 51, 385-397. [CrossRef]

58. Ribot, J.C.; Chhatre, A.; Lankina, T. Introduction: Institutional choice and recognition in the formation and consolidation of local democracy. Conserv. Soc. 2008, 6, 1 .

59. Ostrom, E. Understanding Institutional Diversity; Princeton University Press: Princeton, NJ, USA, 2005.

60. McCay, B.J. Emergence of institutions for the commons: Contexts, situations, and events. In The Drama of the Commons; Ostrom, E., Dietz, T., Dolšak, N., Stern, P.C., Stonich, S., Weber, E.U., Eds.; National Research Council; National Academy Press: Washington, DC, USA, 2005.

61. Robson, J.P.; Klooster, D.J.; Worthen, H.; Hernandez-Diaz, J. Migration and agrarian transformation in Indigenous Mexico. J. Agrar. Chang. 2018, 18, 299-323. [CrossRef]

62. Campbell, D.; Erbstein, N. Engaging youth in community change: Three key implementation principles. Community Dev. 2012, 43, 63-79. [CrossRef]

63. Zetina, J.; McNab, R.B.; Castillo, M. Youth, forests and community in the Maya Biosphere Reserve, Petén, Guatemala. World Dev. Perspect. 2019, 16, 100142. [CrossRef] 
64. De Koning, J.; Cleaver, F. Institutional bricolage in community forestry: An agenda for future research. In Forest-People Interfaces; Wageningen Academic Publishers: Wageningen, The Netherlands, 2012; pp. 277-290.

65. Garnett, S.T.; Burgess, N.D.; Fa, J.E.; Fernández-Llamazares, A.; Monár, Z.; Robinson, C.J.; Watson, J.E.M.; Zander, K.K.; Austin, B.; Brondizio, E.S.; et al. A spatial overview of the global importance of Indigenous lands for conservation. Nat. Sustain. 2018, 1, 369-374. [CrossRef]

66. Berkes, F. Revising the commons paradigm. J. Nat. Res. Resour. Policy 2009, 1, 261-264. [CrossRef]

67. Nayak, P.K.; Berkes, F. Commonisation and decommonisation: Understanding the processes of change in Chilika Lagoon, India. Conserv. Soc. 2011, 9, 132-145. [CrossRef]

68. Agrawal, A.; Ribot, J. Are Ostrom's design principles sufficient for design? In Remembering Elinor Ostrom: Her Work and its Contribution to the Theory and Practice of Conservation and Sustainable Natural Resource Management; Robson, J.P., Davidson-Hunt, I.J., Delaney, A., Lichtenstein, G., Magole, L., Mead, A.T.P., Eds.; Policy Matters Issue 19; IUCN Commission on Environmental, Economic and Social Policy: Gland, Switzerland, 2014.

69. Farrugia, D. The mobility imperative for rural youth: The structural, symbolic and non-representational dimensions rural youth mobilities. J. Youth Stud. 2016, 19, 836-851. [CrossRef]

70. Barnett, R.V.; Brennan, M.A. Integrating youth into community development: Implications for policy planning and program evaluation. J. Youth Dev. 2006, 1, 5-19. [CrossRef]

71. Holden, S.T.; Tilahun, M. Youth as Environmental Custodians: A Potential Tragedy or a Sustainable Business and Livelihood Model? Norwegian University of Life Sciences: AS, Norway, 2016.

72. Aquino Moreschi, A. Cultura, genero, y generaciones en los migrantes. In La Migración y Sus Efectos en la Cultura; Castro Neiro, Y., Ed.; D.F.: CONACULTA: Mexico City, Mexico, 2012.

73. Robson, J.P.; Berkes, F. How does out-migration affect community institutions? A study of two indigenous municipalities in Oaxaca, Mexico. Hum. Ecol. 2011, 39, 179-190. [CrossRef]

74. Robson, J.P.; Asselin, H.; Castillo, M.; Fox, L.; Francisco, S.; Karna, B.; Soriano, M. Engaging youth in conversations about community and forests: Methodological reflections from Asia, Africa, and the Americas. World Dev. Perspect. 2019, 16. [CrossRef]

75. Robson, J.P. The Impact of Rural to Urban Migration on Forest Commons in Oaxaca, Mexico. Ph.D. Thesis, University of Manitoba, Winnipeg, MB, Canada, 2010.

76. Stephen, L. Transborder Lives: Indigenous Oaxacans in Mexico, California and Oregon; Duke University Press: Durham, NC, USA, 2006.

77. Robson, J.P.; Pérez, F.S.; Luja, M.S. Exploring youth-community-forest linkages in rural Mexico. World Dev. Perspect. 2019, 16, 100140. [CrossRef]

78. CCUNESCO (Canadian Commission for UNESCO). Climate Change, Sustainable Development and Global Citizenship: What Are UNESCO and Its Networks' Roles? Concept note prepared for the 57th Annual General Meeting of the Canadian Commission for UNESCO; Canadian Commission for UNESCO: Ottawa, ON, Canada, 2017.

79. ICE [Indigenous Circle of Experts]. We Rise Together: Achieving Pathway to Canada Target 1 through the Creation of Indigenous Protected and Conserved Areas in the Spirit and Practice of Reconciliation; Queen's Printer: Ottawa, ON, Canada, 2018.

80. Restoule, P.; Dokis, C.; Kelley, B. Working to protect the water: Stories of connection and transformation. In Indigenous Research: Theories, Practices, and Relationships; McGregor, D., Restoule, J.-P., Johnston, R., Eds.; Toronto and Vancouver; Canadian Scholars: Toronto, ON, Canada; Vancouver, BC, Canada, 2018; pp. $219-239$.

81. Brondizio, E.S.; Le Tourneau, F.-M. Environmental governance for all: Involving local and indigenous populations is key to effective governance. Science 2016, 352, 1272-1273. [CrossRef]

82. Courtois, V.; Nitah, S. Indigenous-led conservation offers a path to global leadership and reconciliation. Star. 2018. Available online: https://www.thestar.com/opinion/contributors/2018/01/23/indigenous-ledconservation-offers-a-path-to-global-leadership-and-reconciliation.html (accessed on 16 September 2020).

83. Nightingale, A. Commoning for inclusion? Commons, exclusion, property and socio-natural becomings. Int. J. Commons 2019, 13, 16-35. [CrossRef]

84. Robson, J.P. Indigenous communities, migrant organizations, and the ephemeral nature of translocality. Latin Am. Res. Rev. 2019, 54, 103-120. [CrossRef]

85. Quaedvlieg, J.; Merediz, C.; Roca, M.G.; Diaz, K.M.; Suarez, E.C.; Condori, M.Z. Youth perspectives in rapidly changing landscapes: Lessons from Peru. World Dev. Perspect. 2019, 16, 100143. [CrossRef] 
86. Ensor, J.; Berger, R. Community-Based Adaptation and Culture in Theory and Practice; Cambridge University Press: New York, NY, USA, 2009.

87. White, B. Agriculture and the generation problem: Rural youth, employment and the future of farming. IDS Bull. 2012, 43, 9-19. [CrossRef]

88. Fox, J.; Rivera-Salgado, G. (Eds.) Indigenous Mexican Migrants in the United States; Center for U.S.-Mexican Studies; UCSD/Center for Comparative Immigration Studies; UCSD: San Diego, CA, USA, 2004.

89. Tacoli, C.; Mabala, R. Exploring mobility and migration in the context of rural-Urban linkages: Why gender and generation matter. Environ. Urban. 2010, 22, 389-395. [CrossRef]

90. Chiang, Y.; Hannum, E.C.; Kao, G. It's not just about the money: Gender and youth migration from rural China. Chin. Soc. Rev. 2015, 47, 177-201. [CrossRef]

91. de-Brauw, A. Rural youth: Determinants of migration throughout the world. IFAD Res. Ser. 2019, 55, COV1.

92. Evans, K.; Cronkleton, P.; Addoah, T.; Zida, M.; Basefeli, S.; Afagachie, K. Lessons Learned from Participatory Action Research in WAFFI; CIFOR: Bogor, Indonesia, 2019; Volume 254.

93. McDougall, C.; Prabhu, R. Kusumanto. In Participatory Action Research on Adaptive Collaborative Management of Community Forests: A Multi-Country Model; CIFOR: Bogor, Indonesia, 2003.

Publisher's Note: MDPI stays neutral with regard to jurisdictional claims in published maps and institutional affiliations.

(C) 2020 by the authors. Licensee MDPI, Basel, Switzerland. This article is an open access article distributed under the terms and conditions of the Creative Commons Attribution (CC BY) license (http://creativecommons.org/licenses/by/4.0/). 